\title{
MEMETIC IMAGES AND THE USE AND REPRESENTATION OF THE PAST: THE US WAR OF INDEPENDENCE AND DONALD TRUMP'S PRESIDENCY
}

\author{
La imagen memética y el uso y representación del pasado: \\ el caso de la Guerra de Independencia de los Estados Unidos y la \\ presidencia de Donald Trump.
}

\author{
Alberto Venegas Ramos \\ Universidad de Murcia. \\ Reserach Group Humanidades Digitales: Historia y Videojuegos \\ correodealbertovenegas@gmail.com \\ https://orcid.org/0000-0002-5621-7749
}

Recibido: 28-01-2021 - Aceptado: 15-04-2021

Cómo citar este artículo/Citation:

Alberto Venegas Ramos, "Memetic images and the use and representation of the past: the US War of Independence and Donald Trump's presidency", Hispania Nova, 20 (2022): 635 a 659.

DOI: https://doi.org/10.20318/hn.2022.6472
Copyright: (C) HISPANIA NOVA is a duly registered journal, with ISSN 1138-7319 and Legal depositl M 94721998. The texts publsihed in the journal - unless otherwise stated - are licensed under a Creative Commons Attribution-No derivative works 3.0 Spain. They can be copied, distributed and publicly communicated as long as the author, journal and institutions publishing the works are quoted and no derivative work is made. The complete license agreement can be found in http://creativecommons.org/licenses/by-nd/3.0/es/deed.es

debate acerca del tiempo pretérito y su uso en el presente.

Palabras clave: imagen, digital, virtual, cultura visual, teoría de la historia, memoria.

empleando como muestra la famo pintura Washington cruzando el Delaware (1851) del artista Emanuel Leutze y las posteriores modificaciones y adaptaciones de la obra. Partiendo de los últimos estudios de la cultura visual, de la memoria cultural y la literatura previa sobre el tema se analizará un caso de estudio: las imágenes digitales y virtuales elaboradas en torno a la presidencia de Donald Trump y su recuerdo de la guerra de independencia del país. A través de este estudio se tratará definir las formas en las que los nuevos medios se relacionan y emplean el pasado además de establecer a dichos formatos como fuentes válidas para el conocimiento del pasado además de espacios activos de discusión y

\begin{abstract}
The goal of this paper is to study the forms and uses of the past in digitally-created images that are reproduced in virtual spaces using as an example the famous painting Washington crossing the Delaware (1851) by Emanual Leutze and the subsequent changes and adaptations of this work of art. Based on the latest studies of visual culture, cultural memory and previous literature on the subject matter, we will analyse a case study: digital and virtual images created around Donald Trump's presidency and the
\end{abstract}


memories of the country's war of independence. This paper will aim to define the ways in which new media relate to and use the past as well as to consider those formats as valid sources for understanding the past, as well as active spaces of discussion and debate about past times and their use in the present.

Keywords: image, digital, virtual, historical theory, cultural memory, visual culture.

\section{INTRODUCTION}

This paper will attempt to study the nature of digital and virtual images in their most frequent format, memetic, and its relationship with the representation and remembrance of the past, studying representations of US president Donald Trump and the adaptations, reproductions and reappropiations of the painting entitled Washington crossing the Delaware (1851), amongst others, to give the appropriate context. A pioneering study, in our opinion, as the methodology applied by the author is based on hermeneutics, the literature available and the contributions on virtual and digital images offered by visual culture studies, memetics and memory.

This relationship is created around three stages; creation, distribution and reception, with the latter also including transformation. Each of those levels will provide us with different information regarding the social relationship with the past when the creation, reproduction or evolution is made, given that for it to be created, different content, images and methods have been used and combined to offer information regarding the time of creation. This methodological approach, through the study of those stages, is key in order to get closer to the meaning and information offered by the finished image. The first stage is of great importance because it is when the representation and the memory of the past are chosen in a single image, with a meaning that must be understood immediately. The same happens with the second stage, distribution. By analysing how it spreads we can obtain important clues to understand the mood and opinion in specific locations and in specific moments. It brings the past represented by an image to a more recent context, as well as the intertextual elements that allow for a quick identification of the image's meaning. The first section of the paper focuses on analysing those two stages. The third stage, the reception or attention each of those images receives, can be used as a mirror of that specific time and a reflection of the debates and conflicts generated by that reproduction and by the 
reappropiation carried out by the different groups, allowing us to observe the existing discussions. This is of key importance to get to know how relevant the representation was and its meaning in different spaces and times thanks to the analysis of its progressive transformation. This is an aspect we devote the second section to.

Each of those phases structuring our methodological approach will be linked to the characteristics established by Limor Shifman to define memes in digital culture: content, format and "stance" ${ }^{1}$, although we must not forget that each will have its area of importance. During the stage of creation the content will be of extreme importance: How can the memories and the representations of the past be embedded? During the circulation, the format will be important: How will it spread on the screens and which shape will it acquire in the process - image, text, video, etc.-? Each of those forms will be related to different media or channels, and finally, the reception stage, where the "stance" of those who receive it will gain importance in order to know the impact the meme will generate, as the recipient may join in on the dissemination or, in turn, may change its meaning to give it a new meaning layer.

In summary, the question we wish to respond to with this paper is: How do memes use and relate to the past? A question that takes us to two others: Is this a relevant element in the transfer and use of historic knowledge in contemporary times? And, if that is the case, what impact can that knowledge and use have? Those are two questions we do not approach directly in this paper given its scope and length but they will appear indirectly when we look into the first question, analysed via the study of a specific case: history memes, that is, those related to topics linked to the past and that appeared around Donald Trump's presidency, focusing on the above mentioned painting by Leutze.

In order to answer the first question raised, the core question of this paper, we will use a multidisciplinary approach around three different, albeit related, areas of knowledge: the already existing studies on memes, especially the ones by Limor Shifman ${ }^{2}$, Ryan M. Milner ${ }^{3}$ and Bradley E. Wiggins ${ }^{4}$, visual culture studies, with

\footnotetext{
${ }^{1}$ Limor Shifman. Memes in digital culture. (Cambridge: The MIT Press, 2014), pages 39-40.

${ }^{2}$ Limor Shifman, Memes..., op. cit.

${ }^{3}$ M. Ryan Milner. The World made meme. (Cambrige: The MIT Press, 2016).
} 
special attention to the most recent work on digital and virtual images, highlighting the approaches by Juan Martín Prada ${ }^{5}$, Sergio Martínez Luna ${ }^{6}$ and Israel Márquez ${ }^{7}$ and the studies on memory and representation of the past in mass communication digital and virtual media ${ }^{8}$.

\section{DEFINITION, CHARACTERISTICS AND RELEVANCE OF MEMES IN CONTEMPORARY VISUAL AND DIGITAL CULTURE}

In this paper, we will use the concept of meme not linked to biology and genetics, we will focus on its definition as a digital or virtual visual element, distributed by electronic means, that conveys a message linked to an electronic image. According to Shifman a meme is: "a) a group of digital items sharing common characteristics of content, form and/or stance, which (b) were created with awareness of each other, and (c) were circulated, imitated, and/or transformed via the Internet by many users" ${ }^{9}$, a very similar definition to that of Milner, who defined memes as: "linguistic text, images, audio and videos created, circulated and transformed by countless cultural participants via large networks or groups" 10 .

Both definitions share common characteristics: a) their digital nature: b) their circulation via virtual networks; c) the need to identify the meme's discourse within the community with whom it is shared; d) and the participation of countless participants in its creation, distribution and transformation, making it impossible to indicate a clear authorship, assigning it to whoever gave it meaning ${ }^{11}$. This paper will include images

\footnotetext{
${ }^{4}$ Bradley Wiggins. The discursive power of memes in digital culture (Nueva York: Routledge, 2019).

${ }^{5}$ Juan Martín Prada. El ver y las imágenes en el tiempo de internet (Barcelona: Akal, 2018).

${ }^{6}$ Sergio Martínez Luna. Cultura visual, la pregunta por la imagen (Vitoria-Gasteiz: Sans Soleil, 2019).

${ }^{7}$ Israel Márquez. Una genealogía de la pantalla. Del cine al teléfono móvil. (Barcelona: Anagrama, 2015).

8 Alberto Venegas RAmos. Pasado interactivo: memoria e historia en el videojuego (Vitoria-Gasteiz: Sans Soleil, 2020).

${ }^{9}$ Limor Shifman, Meme..., op. cit., page 41.

${ }^{10}$ M. Ryan Milner. The world made..., op. cit., page 1.

${ }^{11}$ According to Joan Fontcuberta, the merit of the creation rests in the granting of a meaning to digital images: "Where can the merit of the creation rest then? The answer seems simple, in the ability to give the image an intention and sense, in giving it significance. All in all, the merit will rest in being able to express an idea, in having something interesting to say and knowing how to express it using
} 
that have been modified by countless users (images 2, 5 and 6) as well as others that have been created with a meme format by one single author but that were shared massively in the social media ${ }^{12}$ by countless users who gave it a new meaning thanks to their comments and footnotes, as well as a space in the collective imagination thanks to its dissemination. All of them are specific features of virtual images already mentioned by writers such as José Luis Brea ${ }^{13}$ and Martín Prada. ${ }^{14}$ In this paper we will mainly focus on the study of the discourse and the meme's ability to grab the attention as well as on the images created under a meme format. To do this, we will focus on two specific aspects: the meme creation, and the significant use or not ${ }^{15}$ of that meme in the public arena, according to the methodological structure presented in the first few pages of the paper. Nevertheless, we will also offer some final reflections on the appropriation and reappropriation of images that the virtual space offers.

According to the pioneering work of Shifman, memes whose intention is to politically intervene in the public arena of a community can have three main goals: 1) a way of persuasion or political defence, 2) grassroots action memes to connect to a political community, to mobilise and coordinate it politically and, 3) as a form of expression and public discussion ${ }^{16}$. Nevertheless, to fulfil those goals according to Wiggins, they must have certain ideological, semiotic and intertextual characteristics

photographs", in Joan Fontcuberta. La furia de las imágenes, (Barcelona: Galaxia Gutenberg, 2016), page 53.

${ }^{12}$ Image 1 in this paper was shared in the social network Twitter 7,782 times with no added comment, 4,999 times with a new footnote changing its meaning and it received 52,770 positive notifications (such as "Like") (Seen on the 13 ${ }^{\text {th }}$ of April, 2021, in https://twitter.com/AZGOP/status/1343705320607121410). Moreover, it was the subject of numerous changes and deformations, as can be seen in this press article. Claire Goforth, "People cannot stop dunking on viral painting of Trump in a Revolutionary War uniform", Daily Dot, 30 ${ }^{\text {th }}$ of January, 2020 https://www.dailydot.com/debug/trump-revolutionary-waruniform-painting-memes [Seen on $13^{\text {th }}$ of April, 2021].

\footnotetext{
${ }^{13}$ José Luis Brea. Las tres eras de la imagen (Barcelona: Akal, 2010), pages 67-72.

${ }^{14}$ Juan Martín Prada. El ver..., op. cit., page. 95.

${ }^{15}$ Understanding this meaning as the second definition entry of the RAE: "considering it important for representing or meaning something" that is, those memes have a political discourse objective in the broadest sense of that concept, as an intervention in the public affairs of a political community with a representation, opinion or intervention.
}

${ }^{16}$ Limor Shifman, Meme..., op. cit., pages 122-123. 
that make it possible to capture the attention and generate a useful expressive $\operatorname{discourse}^{17}$.

With regard to the ideology part, Wiggins uses the work of Barthes to present his definition of the meme's ideological element, which we will also use in this work. In his communication's theory, Barthes links ideology to the idea of the myth: "Barthes refers to the ways myths are used to talk about a topic, but only to the extent of capturing the desired content, leaving out anything that could delegitimise the argument and presume that everything is the same as a fact" ${ }^{18}$. In the different history memes, we will see that not all the past's complexity is shown, only the elements needed to talk about a specific topic, carefully as not to spoil the main argument of the image and offering through that image a simple answer to a specific situation. In this case, it will be specially important that the recipients of the message share the same referents, that is, that they share the same myth or ideology as the meme's creators so that it is fully understood and grabs the attention, thus exercising an expressive discourse that manages to mobilise recipients around the "myth" that is represented in the meme. Or the opposite, to provoke an answer to the meme, transforming it and giving it a new meaning that is a calling to other communities. We must not forget that, as Wiggins said: "memes are produced to mean something and in the process of interpretation and comprehension, this actually becomes a process of ideological formation" ${ }^{19}$.

As for the semiotic part and resorting once again to Wiggins, we must bear in mind that:

In a sense, we can view Internet memes as a real-world representation of the more abstract claims associated with Derrida's view that signs refer to other signs that refer to other signs. (...) Namely, a culture which is so saturated with media usage recursively produces and reproduces texts for (instant) consumption. Despite the potential for rapid consumption and production, Internet memes persist. They possess the potential to permeate all forms of discourse

\footnotetext{
${ }^{17}$ We understand the expressive discourse related to the meme as per Wiggins: "having the ability to do something, that is, to participate in the construction and reconstruction of social relations in online spaces. However, the social relations are also constructed and reconstructed offline given the degree to which individuals remember, create, speak, etc."The discursive power..., op. cit., page 21.

${ }^{18}$ Ibidem., page 27.

${ }^{19}$ Ibídem., page. 30.
} 
precisely due to the inherent affordances of digital culture and the use of online forms of communication ${ }^{20}$.

Thus, it will be crucial to recognise first what the meme represents, how it does it and the when as well as the where. To answer those questions, we will first need to place it in time and space and to connect it to its context. Once all those questions have been answered, we must apply an archaeological method that manages to generate a genealogy of that image that allows us to recognise the above-mentioned signs in order to discover its ultimate meaning. A genealogy that must be complemented with horizontal research to discover what relationship an image has with others and how they coexist in the media ecosystem. A task for which the concepts of "dialectical image" by Walter Benjamin ${ }^{21}$ and "deviation" by Guy Debord wil be of great importance ${ }^{22}$. Two concepts that, when joined to others, ${ }^{23}$ must be taken into consideration with every image but which are even more relevant in this case, given the progressive transformation process digital images undergo. A transformation process in which intertextuality gains special relevance, as it strengthens the meaning of the expressive discourse issued by echoing in the recipient an "aesthetic memory" ${ }^{24}$ and linking the

\footnotetext{
${ }^{20}$ Ibidem., pages 32-33.

${ }^{21}$ According to José María de Luelmo Jareño in his study on this not very elaborated concept in the work of Walter Benjamin: "the dialectical image is, therefore, a trigger that faces a static approach to history, a bet on the infinite significance of an image, without impositions or closures. In fact, states Benjamin, "only dialectical images are really historic, not archaic", as they remain unfinished, fully open to new readings and willing to communicate meaning to perpetuity", by José María Luelmo Jareñoa. "La historia al trasluz: Walter Benjamin y el concepto de imagen dialéctica", Escritura e imagen, 3, 2007, pages 163176, page 172 .
}

${ }^{22}$ According to Joan Fontcuberta, the concept of deviation coined by Debord refers to "the kidnapping of important images for the creation of counter-messages that are not subjected to the visual establishment" in Joan Fontcuberta. La furia..., op. cit. page 57.

${ }^{23}$ In order to consider appropriately the memetic virtual image, certain considerations regarding the materiality of the image developed by Sergio Martínez Luna will be key. "There is a materiality in images that is recognisable in digital images. Although they depend on logarithmic operations to appear on the screen, those processes require the support of an infrastructure or a hardware that will make them visible, as well as artefacts with a specific material and tactile density. Digital images are displayed on screens that have their own sensoriality, combining visual, tactile and auditory dimensions. Virtual interaction is applied to the technical and artefactual materiality that enables communication and telematic participation networks, The material approach to the digital artefacts presents them as devices where discussion dynamics, social appropiations and technological artefacts take place. The materiality of the image, understood as the physical and technological materiality of the photograph, with its associated uses and functions, collides with the digitisation processes. But that does not mean materiality is overcome. The question has to turn towards the understanding of the material conditions that enable the manifestation and circulation of digital images" Sergio Martínez Luna, Cultura visual..., op. cit., page 65.

${ }^{24}$ Alberto Venegas RAmos, Pasado interactivo..., op. cit., pages 109-127. 
image to other cultural objects ${ }^{25}$.. We illustrate this approach with some memes we have chosen and with another series of images that reflect more broadly the concepts hereby treated.

Since our subject matter is now defined and characterised, we will now demonstrate its relevance in contemporary culture and a specific aspect of special significance: its ability to trigger political manifestations beyond the virtual domain ${ }^{26}$.

Anthropologist Angela Nagle pinpoints the last few days of May 2016 as the time of a radical turnaround regarding the ideas on the so-called networked society. From the ideas of optimist sociologists such as Manuel Castells, who forecast the appearance of different revolutions without leaders organised by the social networks that would lead to more open and democratic societies ${ }^{27}$, we moved to a more negative viewpoint, where social networks are considered a threat for society ${ }^{28}$. This radical turn was due, to a large extent, to the mobilisation caused by the success of several memes that carried out the functions Shifman had described: uniting different communities and mobilising them, ${ }^{29}$ although in this case with different intentions to those proclaimed by Castells. Memes that, not in few occasions, were related to the country's history. ${ }^{30} \mathrm{~A}$ change that came up a few months before the election of Donald Trump and that,

\footnotetext{
${ }^{25}$ According to Wiggins, intertextuality with regard to memes must be understood broadly: "the point here is that intertextuality should not be thought of as mere associations with other texts, for the singular purpose of adding meaning. Rather, intertextuality is purposeful, unavoidable and ubiquitous. It is less helpful to think of individual texts, referring to other texts in the process of making meaning as intertextual. Instead all texts are intertexts, references to other content, citations to previous work, allusions, parody, pastiche, etc. permeate all texts, and this is especially relevant and applicable to internet memes as a genre of online communication."Bradley Wiggins, The discursive power..., op. cit., page 35 .

${ }^{26}$ Although we speak of the virtual world, we must understand it as Israel Márquez said: "we do not have the slightest sense of irreality in our relations with objects [cibersecreen simulated] and people [with the different icons, texts, photographs and avatars that represent it in the screen] In the culture of simulation the categories of what is real and what is virtual stops working as a simple dichotomy and becomes and blends in a complex manner" Israel Marquez, Una geneaología ...op. cit., page 179.

${ }^{27}$ Manuel Castells. Redes de indignación y esperanza: los movimientos sociales en la era de internet (Madrid: Alianza, 2012).

${ }^{28}$ Marta Peirano. El enemigo conoce el sistema. (Barcelona: Barcelona, 2018).

${ }^{29}$ Francisco Veiga, Carlos González-Villa, Steven Fortin, Alfredo Sasso, Jelena Prokoplijevic, y Ramón Moles. Patriotas indignados: sobre la nueva ultraderecha en la Posguerra Fría: Neofascismo, posfascismo y nazbols. (Madrid: Alianza, 2019), page 266.

${ }^{30}$ Oskar Aguado Cantabrana and Juan Pérez Mostazo. "Los bárbaros asaltan el Capitolio mientras Nerón incendia Washington", Proyecto ANIHO. Antigüedad, nacionalismos e identidades complejas en la historiografia occidental: Aproximaciones desde Europa y América Latina (1789-1989). 15 ${ }^{\text {th }}$ of January 2021, https://aniho.hypotheses.org/2075 [consulted 16th of January, 2021].
} 
according to Nagle and other scholars, ${ }^{31}$ was key to his appointment as president of the United States ${ }^{32}$. With this information we could then consider that, in fact, the expressive discourse of memes is relevant to the social and political current situation to the extent that some countries have censored their use $\mathrm{s}^{33}$.

In the same way memes are relevant in the contemporary public sphere, so should they be for historians, because memes have become, thanks to their massive use, a new source of special relevance for the profession. Scholars Lisa Bogerts and Maik Fielitz carried out in their work entitled "Do you want meme war?» Understanding the visual memes of the German far-right" ${ }^{34}$ a detailed study regarding the use of images from the past converted into memes whose intention is to mobilise and add participants to different organisations of extreme far-right. Of all those, the initiative entitled "Germanic reconquest" was the most relevant of all as it favoured the AfD on the 2017 elections ${ }^{35}$. History memes created by that virtual initiative used as sources the Nazi Germany and the medieval times, especially the contemporary imaginary created around the idea of the crusades as an anti-Islamic expression. ${ }^{36}$ An use of images from the past, that, according to the researchers, had one clear goal: "Although historic "sources" provide the authority of visual "evidence" to back arguments with a transhistoric legitimacy of a long tradition, mixing it with more contemporary style characteristics gives the narrative a more "juvenile" appearance" ${ }^{37}$. Other scholars have studied history memes to get to know, understand and explain the Ukrainian and Russian nationalist

\footnotetext{
${ }^{31}$ Angela Nagle, Muerte a los normies. Las guerras culturales en internet que han dado lugar al asceso de Trump y la "alt-righ", (Barcelona: Orciny Press, 2019).

32 On this topic, please refer to S. Andrew Ross and J. Damian Rivers. "Digital cultures of political participation: Internet memes and the discursive delegitimization of the 2016 US Presidential candidates". Discourse, Context \& Media, 16, 2017, pages 1-11.

${ }^{33}$ It is the case of China, whose government has decided to censor certain memes and to consider their use and reproduction a criminal offence, in Bradley Wiggins, The discursive power...op. cit., page 78.

${ }^{34}$ Lisa Bogerts and Maik Fielitz. "«Do You Want Meme War?»: Understanding the Visual Memes of the German Far Right.", in Post-digital cultures of the far right: Online actions and offline consequences in Europe and the US, coordinated by Maik Fielitzk and Nick Thurston. (Verlag: Transcript, 2019). 137-153

${ }^{35}$ Ibidem, page 140.

${ }^{36}$ Ibídem, pages. 144-146.

${ }^{37}$ Ibidem, page 146.
} 
discourses within the Donbass conflict ${ }^{38}$ or the memories of the Second World War in Russia and their role in the contemporary national identity of the Eurasian country ${ }^{39}$. The attention given by historians to this cultural manifestation is still minor but, given its relevance, it would be a mistake not to study it appropriately, and as Emily Apter states: "They act as echo chambers and visual archives for political discussions and cultural wars. They are weapons of political war" ${ }^{40}$.

In summary, a meme is a virtual creation made up of different materials, although the image and the text can be considered the key elements, that is created and reproduced via virtual media, and then transformed due to the participation of different cultural participants. It must be recognised by a specific community and, according to the ideological, semiotic or intertextual traits, it may lead to a reaction amongst recipients, generating a political, social and cultural manifestation outside the virtual sphere. Now that the definition, features and relevance have been clearly illustrated, let's now draw the relationship that it has with the past.

\section{HISTORY MEMES: REPRESENTATION AND USE OF THE PAST}

\section{The construction and dissemination of memes: retro-places and forms of remembrance.}

In order to offer a satisfactory explanation to the relationship that exists between memes and their use and representation of the past, as well as to place that relationship in the theoretical framework established above, we are going to use a key method: the one described at the beginning of this study. This effort will be complemented by also looking into the academic literature on the topic and analysing, in light of all that information, different history memes that came up around Donald Trump's presidency in the United States. However, before we start documenting specific cases we will try to

\footnotetext{
${ }^{38}$ Lyudmyla Pavlyuk. "Memes as markers of fakes and propaganda topics in media representations of the russian-ukrainian conflict". Journal of the National University "Politécnica de Lviv". Series: Ciencias Periodísticas, 3, 2019 pages. 87-94.

${ }^{39}$ Mykola Makhortykh. "Everything for the Lulz: Historical memes and World War II memory on Lurkomor'e". Digital Icons: Studies in Russian, Eurasian and Central European New Media, 13, 2015, pages. 63-90.

${ }^{40}$ Emily Apter, "Alphabetic Memes: Caricature, Satire, and Political literacy in the Age of Trump", October Magazine, 170, 2019, pages 5-24, pages 23.
} 
offer a general answer to the how: How do history memes represent the past? In order to provide a good answer we must once again revisit the studies on contemporary virtual culture and, more specifically, those devoted to the image. According to Martín Prada:

The former depth of the signs has gradually replaced its strength by the intensity of its presence. Things are now shown with their most basic obvious elements, enabling their immediate understanding. Time for arguments is shortened, everything must convince us instantly. Sense is no longer the result of work and becomes immediate, present before our eyes, translated into seductive visual compositions. That is the reason why it is increasing less likely that images will carry mystery, suggestive at most of a nervous suspense after long expectation. That is why when we speak of the role of art in the production of "counterimages" we must do it, precisely, with a specific visual production that, above all, leaves aside establishing a mere immediacy relationship with the spectator, using visual composition that that emit a slower, more dense light, that need to have a longer optical digestion ${ }^{41}$.

The useful life of memes is short-lived; they do not last in time except in very specific cases. Their life on the screens is conditioned by the attention they receive. To be important and persist in time, they must be inevitably clear and direct. As mentioned by Martín Prada, they must be immediately similar to the most obvious elements of whatever they represent in order to facilitate their immediate understanding. In the case of representations of the past, they must be established under the form of "retroplaces" $^{42}$ that is:

...facts, objects and ideas that often appear repeated in the mass communication media and that tend to recall a complete historic moment. An element that recalls and tries to rebuild an idealised, light and simplified past, easily recognisable and out-of-time with the goal of becoming an object of cultural consumption or aesthetic ornament $^{43}$.

The representation of the past contained in the meme makes references, then, to elements easily recognisable by the public, given their mass reproduction in the media with the aim of being recognised immediately. We can use the image below to illustrate

\footnotetext{
${ }^{41}$ Juan Martín Prada, El ver..., op. cit., page 25.

${ }^{42}$ Alberto Venegas RAmos, Pasado interactivo..., op. cit., pages. 128-147.

${ }^{43}$ Ibidem, page 128 .
} 
that characteristic of special relevance for the contemporary virtual image and its relationship with the past:

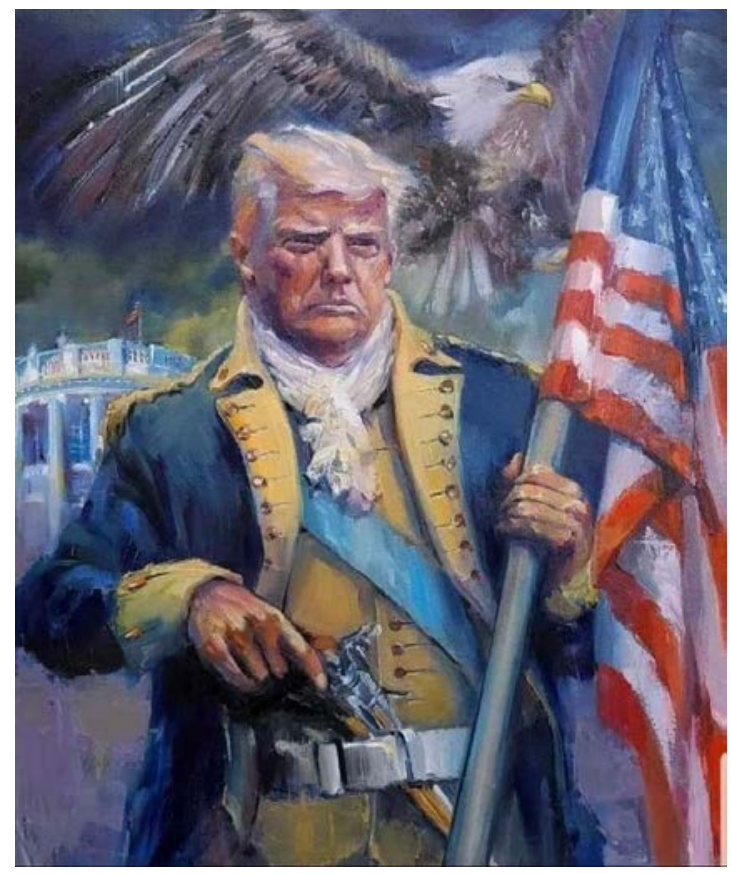

Image 1: Image created via digital media and shared in social network Twitter by the Republican Party of Arizona on the $29^{\text {th }}$ of December, 2020.

This image shared by the US Republican Party and that obtained important notoriety in $2020^{44}$ is made up of different elements that link it immediately to the period of the War of Independence by bringing together different symbols: the flag, the gun, the eagle and the White House in the background, a building built in 1792 and inhabited for the first time in 1800. Apart form the clear anachronisms of this image, it is obvious that it links the figure of the president to a time of special relevance for the country's national identity. As mentioned by Bogerts and Fielitz, those images have the objective of giving authority to the characters represented with the visual evidence, backing the decisions of those represented and giving the image a transhistoric legitimacy of a long tradition, linking it to a mythical past. This was not the only time that this comparison was brought up; on the $4^{\text {th }}$ of July 2018, the president's son shared this meme in the social networks:

\footnotetext{
${ }^{44}$ Please refer to note 12.
} 


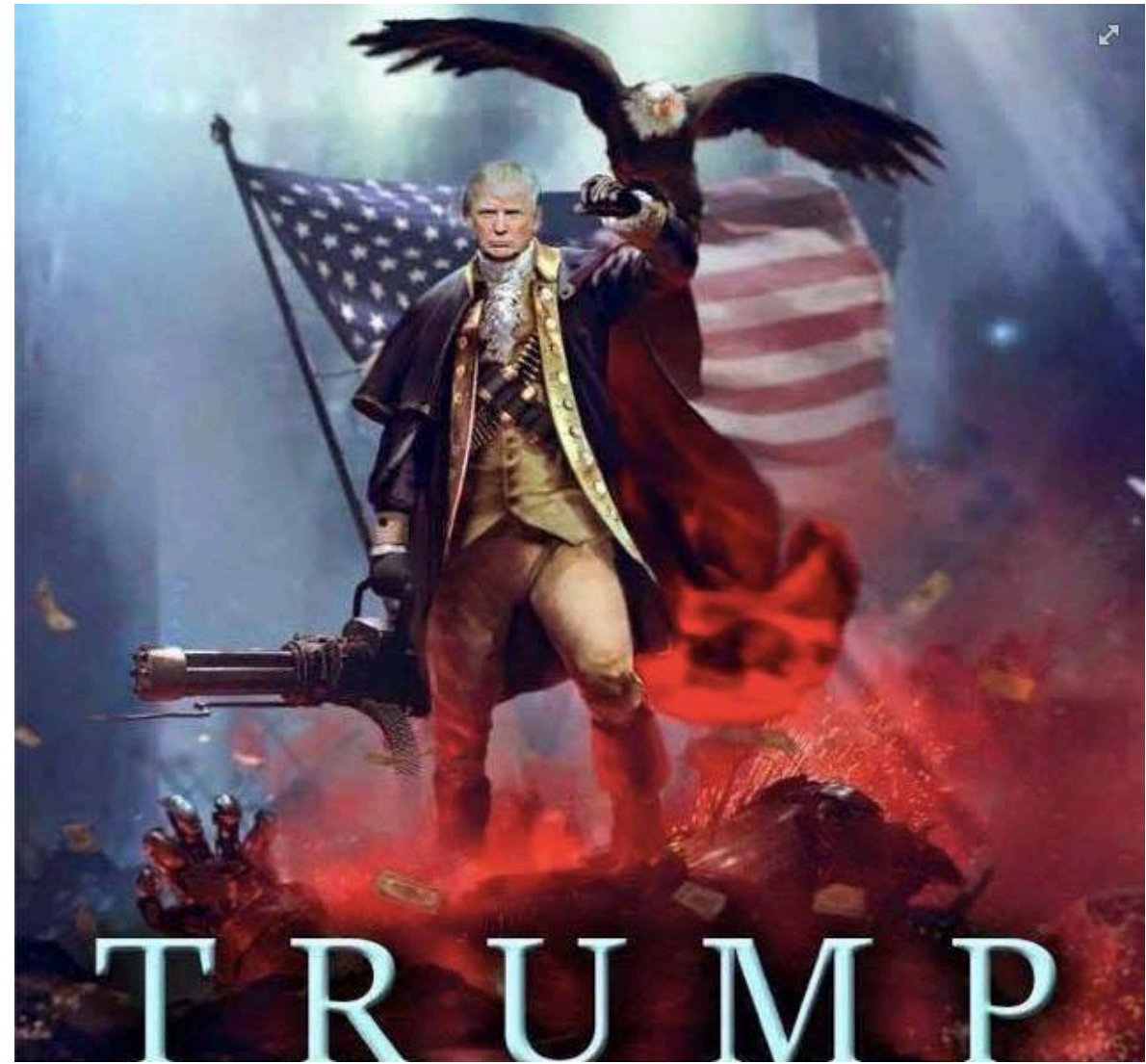

Image 2: Virtual image shared by Donald Trump Jr., in his social networks.

We can observe the same elements: the flag, the eagle, the weapon, now changed for one of greater calibre and the clothing. This specific image was a transformation of a previous one included in the video game Call of Duty (Activision Blizzard, 2003-2020), that originally represented the figure of the first US president, George Washington, and that was then modified by anonymous users. ${ }^{45}$ The use of war and military images is also a common feature of memes generated by the president's supporters, as observed by researcher Apter ${ }^{46}$.

In both virtual images, the heroic figure of the president appears linked in a clear, obvious and direct manner to the country's war of independence and to some values associated to it by contemporary memory culture. The "American Revolution" is

\footnotetext{
${ }^{45}$ After being published in Donald Trump Jr.'s profile in Instagram, the image received 119,904 positive interactions and over 4000 comments. Seen on https://www.instagram.com/p/CCSCNcclDfS/ [Consulted on 13th April 2021]. An image taken on by the president's son.

${ }^{46}$ Emily Apter, “Alphabetic Memes...”, op. cit., page 7.
} 
one of the past events more present in the lives of US citizens ${ }^{47}$ and its current reception, according to Schocket, has been divided into two views: essentialist ${ }^{48}$ versus organicist ${ }^{49}$. The first "is based on the view that there was an American Revolutions led by demigods resulting in an inspired governmental structure and leaving a legacy from which straying would be treason and result in the nation's ruin" ${ }^{50}$ and the second: "agree with essentialists in that the nation has changed over the last two centuries, but they have a different sense of how we think of the past. For organicists, there are many pastas that may share elements but no one fixed truth. Rather, the past must be interpreted to be understood." ${ }^{51}$ Two views that could be included within the categories established by Todorov about literal memory, preserving the past unchanged and exemplary memory, using the past to try to improve the present ${ }^{52}$. In both images, Trump represents the essentialist view ${ }^{53}$ and uses iconography, and so do his followers, of the American Revolution as a political tool $1^{54}$ as we could observe on the $6^{\text {th }}$ of January 2021, when the political community closer to the president tried to attack the Capitol carrying all sorts of patriotic symbols ${ }^{55}$ in reference to the time of independence and the essentialist way of viewing $\mathrm{it}^{56}$.

47 M. Andrew Schocket. (2015). Fighting Over the Founders: How We Remember the American Revolution. (New York: NYU Press, 2015), page. 3.

${ }^{48}$ Ibídem, page 4

${ }^{49}$ Ibidem, page 5 .

${ }^{50}$ Ibídem.

${ }^{51}$ Ibidem, page 5.

52 Tzvetan Todorov. Los abusos de la memoria. (Barcelona: Paidós, 2013), pages 33-34.

${ }^{53}$ It represents this view for different reasons: his political alliance with the Republican group Tea Party, one of the figureheads of that view (Schocket, M. Andrew, Fighting over..., op. cit., page 162), because of his followers' community, amongst which we can find groups such as the "III Percent", that has an official flag with the date 1776, and whose name comes from the alleged three percent of patriots of the whole population of the 13 colonies that were needed to throw out the British and proclaim independence (Mark Giglio. "A Pro-Trump Militant Group Has Recruited Thousands of Police, Soldiers, and Veterans". The Atlantic. 1st of November, 2020, https://www.theatlantic.com/magazine/archive/2020/11/right-wingmilitias-civil-war/616473/); and because of his political statements in which he turned his political opponents into alleged enemies of the nation (Anthoyn Zurcher. "The birth of the Obama 'birther' conspiracy". BBC. $16^{\text {th }}$ of September, 2021, https://www.bbc.com/news/election-us-2016-37391652).

${ }^{54}$ R. Julia DeCook. "Memes and symbolic violence:\# proudboys and the use of memes for propaganda and the construction of collective identity". Learning, Media and Technology, 43(4), 2018, pages 485504.

55 They did not only go in with flags related to the end of the $18^{\text {th }}$ century, the use of the confederate flag also had a huge impact, giving them a new meaning and function in the US reactionary visuality. Valeria 
Thus, this use of the past, as well as other tools and methods, was able to present an easily-accessible past to citizens due to the common presence of those symbols in mass media (semiotics). This visual over-abundance of specific elements of the past in the contemporary media ecosystems also allows everyone to share a series of visual referents (intertextuality) makes it possible for us, with almost immediacy, to understand the image's intention, a representation of the past that, in this case, is associated to several values, emotions and ideas (ideology) that were able to question and provoke an answer in agreement with the three goals described by Milner: political defence, connection with a political community to mobilise and coordinate it politically and to lead to different forms of expression and public discussion ${ }^{57}$.

\section{The reception and deformation of memes: lightness and density, images and counterimages}

Another characteristic defined by Martín Prada is that the sense of those images is no longer the result of work and becomes immediate, present before our eyes, translated into seductive visual compositions. In the previous images we have been able to see that. The past is not created, it is the present, the figure of the former president, the one that is embedded into the past before our eyes so clearly and directly in a heroic composition that grabs our attention. Nevertheless, that composition has also been used in the north-American country for the opposite purpose, to condemn the president's actions and appeal to other ways of remembering the past of a country, the organicist view. If memes and visual images that represent the past as per the essentialist or literal view tried to declare themselves as the single successors of an unchanged past time of the United States, the others tried to use that same past with the intention of repairing the present, creating with the former a dialectic relation.

In the section devoted to the definition of memes we saw that they were images in constant transformation by the different cultural participants. This is what has happened

Sinclair-Chapman. "(De) Constructing symbols: Charlottesville, the confederate flag, and a case for disrupting symbolic meaning". Politics, Groups, and Identities, 6(2), 2018, pages. 316-323.

${ }^{56}$ During the attempted attack on the Capitol, as well as many memes turned into flags and several items of clothing, we could observe Gadsden flags, flags with 12 stars, flags with the 1778 date, etc. Greenlee, Kaylee. "Photos: The Political Symbols Of The Capitol Riot". Dailycaller. $7^{\text {th }}$ of January, 2021, https://dailycaller.com/2021/01/07/political-symbols-washington-dc-capitol-riot/

${ }^{57}$ Limor Shifman, Meme...op. cit., pages 122-123. 
with the well-known painting Washington crossing the Delaware, work of Emanuel Leutze dated 1856, which has undergone a process of transformation, recreation and reproduction that perfectly exemplifies the aforementioned.

In this famous painting we can see general Washington in a heroic position guiding his soldiers to the battle against the British soldiers. Washington represents in this image, and in the US memory ${ }^{58}$ about the conflict, the incorruptible hero who is not willing to compromise until he reaches victory ${ }^{59}$. Very quickly after Trump was elected president, images appeared that put the president's figure in an equal position both in digital and material format, as well as subsequent caricatures of this imitation in meme format.

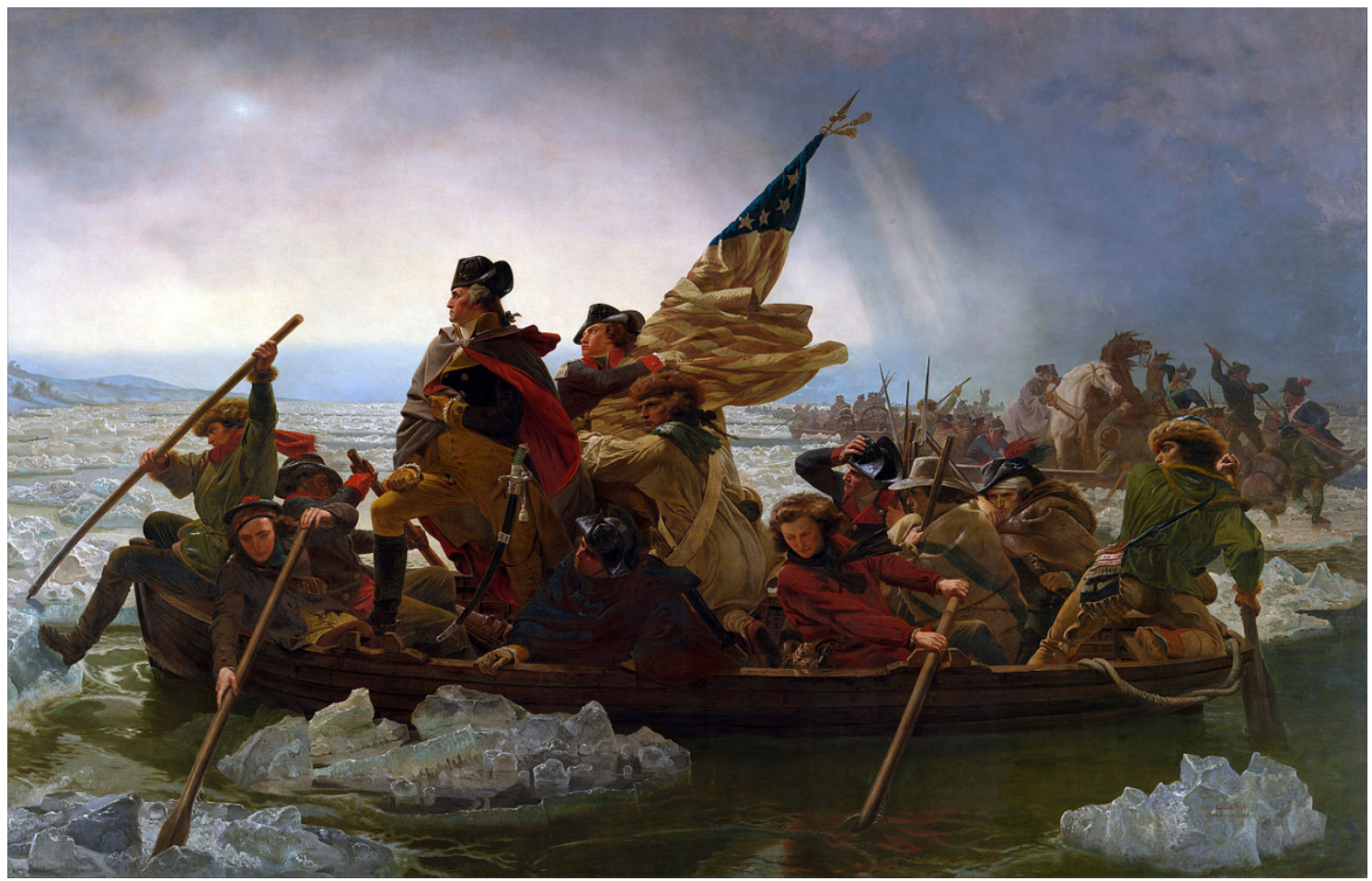

Image 3: Washington crossing the Delaware.

\begin{abstract}
${ }^{58}$ It is worthwhile pausing for a minute to refer to the original intention of the painting. According to Barbara S. Groseclose, this work of art is the best known history painting amongst US citizens and has managed to become, in itself, a symbol of patriotism. However, the artist painted it with the intention of making a political statement about Germany, and not about the United States. The original meaning of the painting by Leutze must be understood as an allegory of the triumph of democracy at a time, in the years following 1848, in which the attempts to establish a definitive German congress had failed. Therefore, it is interesting that this image transformed a minor event of the US war of Independence into a mythical moment that has generated, afterwards and independently from its original intention, a quasi-mythical discourse around the figure of Washington largely recognised by most US citizens and the utmost symbol of patriotism. S. Barbara Groseclose. "Washington Crossing the Delaware:" The Political Context". American Art Journal, 7(2), 1975, pages 70-78.
\end{abstract}

${ }^{59}$ Schocket, M. Andrew, Fighting over..., op. cit., page 162. 


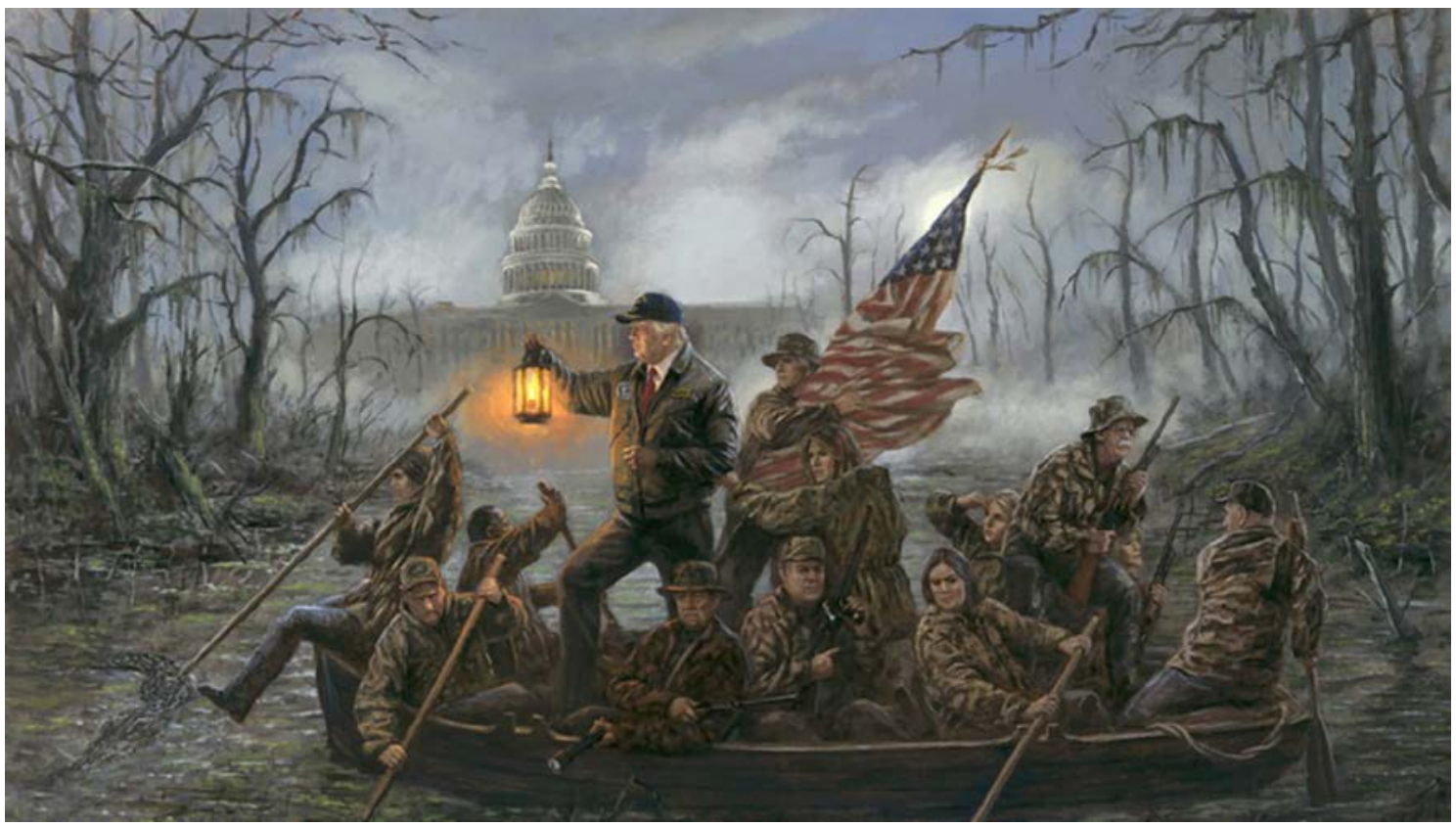

Image 4: Crossing the swamp, painting by Jon McNaughton (2018).

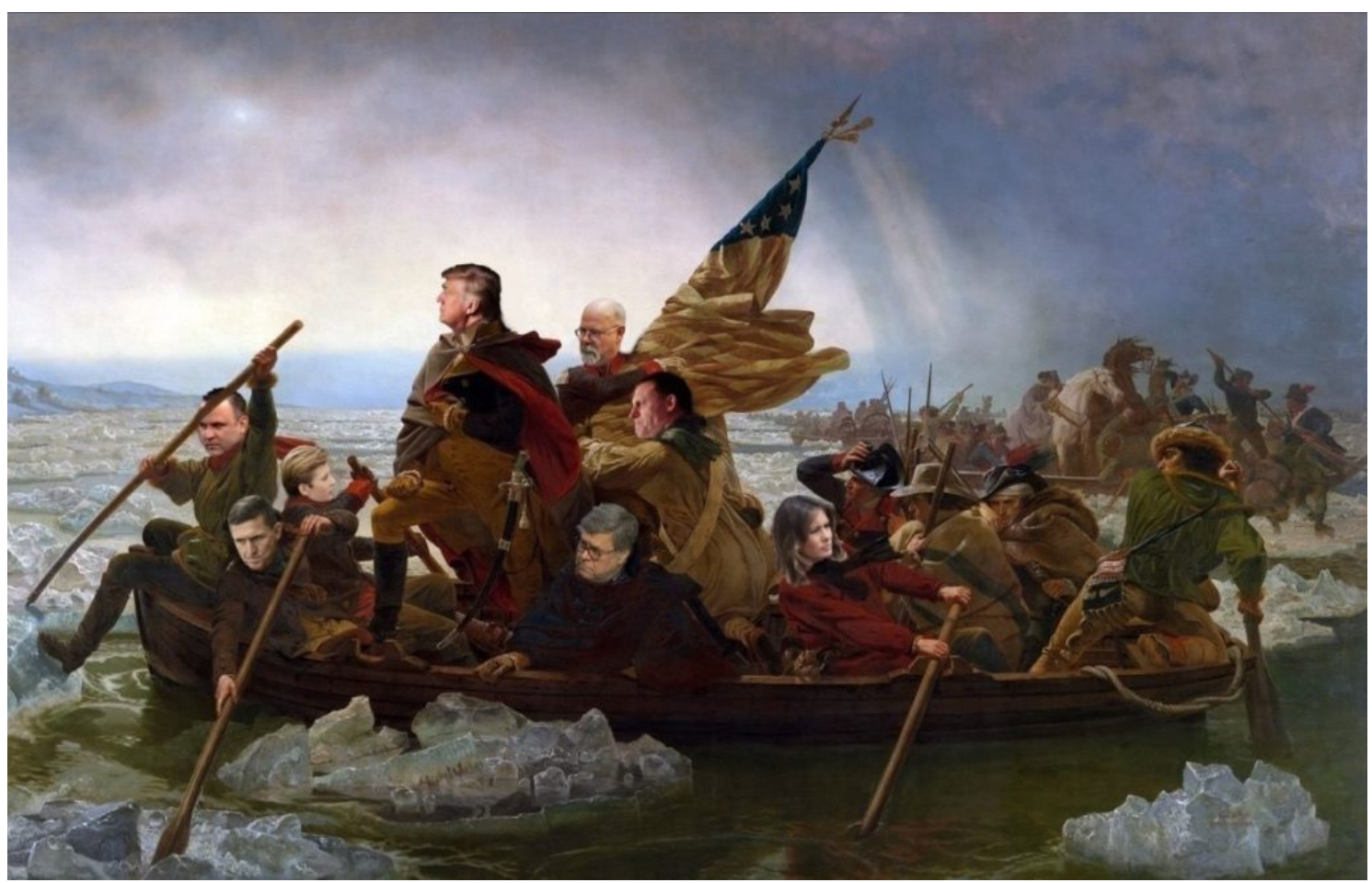

Image 5: Meme created by anonymous supporters of Donald Trump to extol the comparison with the first president of the United States ${ }^{60}$.

${ }^{60}$ This image was shared for the first time in the social network Twitter on the $29^{\text {th }}$ of January. 2020 from an account currently suspended (https://twitter.com/DOITQ GO17/status/1222418555813212160). However, it led to huge controversy and generated numerous appropiations in that social network (https://twitter.com/search?q=\%22trump $\% 22 \% 20$ crossing $\% 20$ delaware\&src=typed_query\&f=image) 
Both images represent the president and the past under the view already observed of essentialist memory. They emulate what is represented in the original image with the intention of transforming the protagonist' character into a simulation of the first character. It brings back the past, perceived as unchangeable, to justify and legitimise the present, making him the protector and defender of its legacy in current times. However, after them, a long series of digital and virtual changes were made to both images (image 4 and 5) that tried to show the distance between the work of Leutze and the values that the US memory gives to it, with the intention of criticising the presidency of Donald Trump and its use of the past. Their intention is to ridicule the goals of the second image and its comparison with the past, maintaining the necessary elements that manage to identify it as a response.

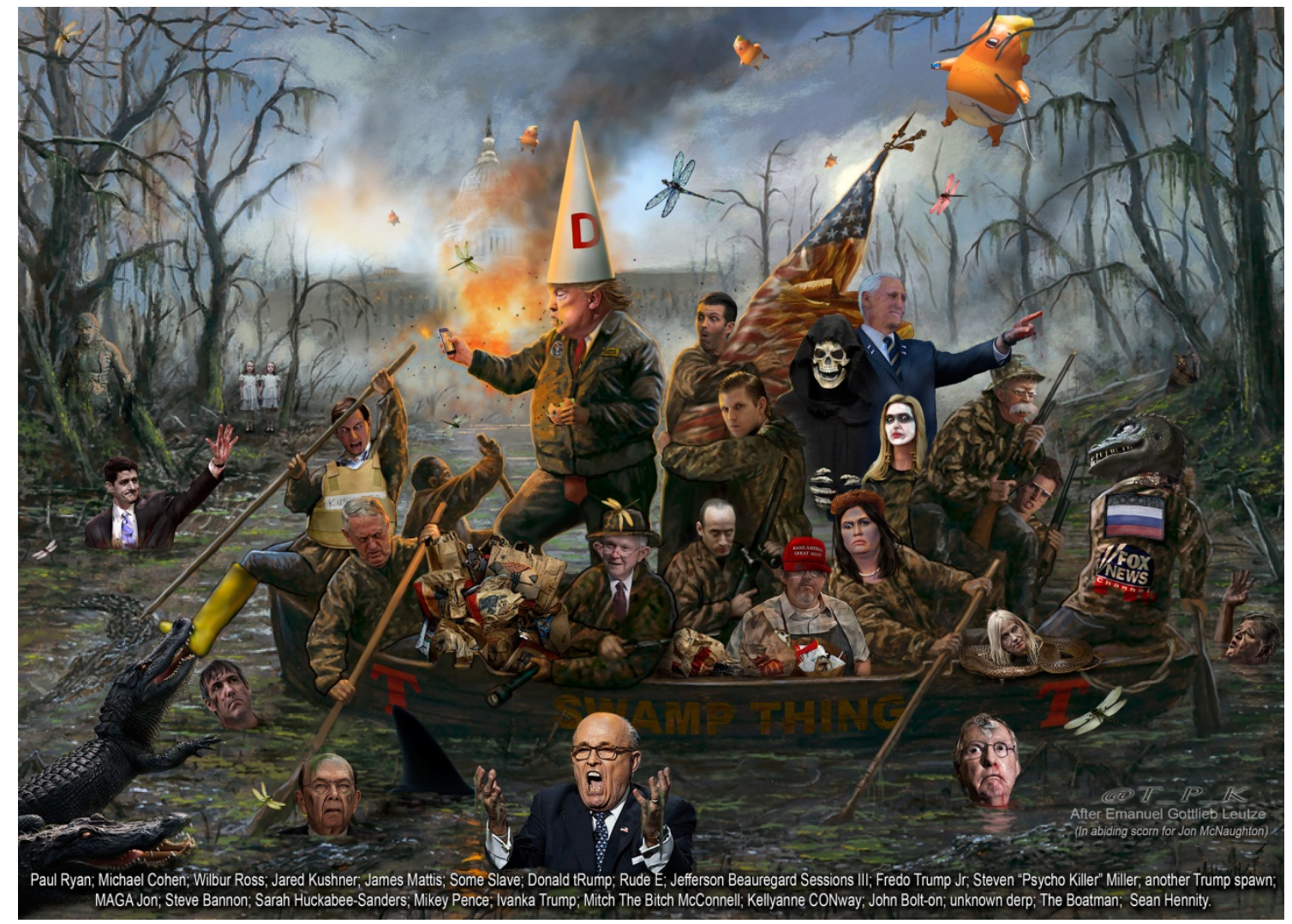

Image 6: Changes to the painting entitled "The Swamp Thing".

where users of that social network showed their agreement or disagreement with what was being represented with the use of photmontage of the original image. 


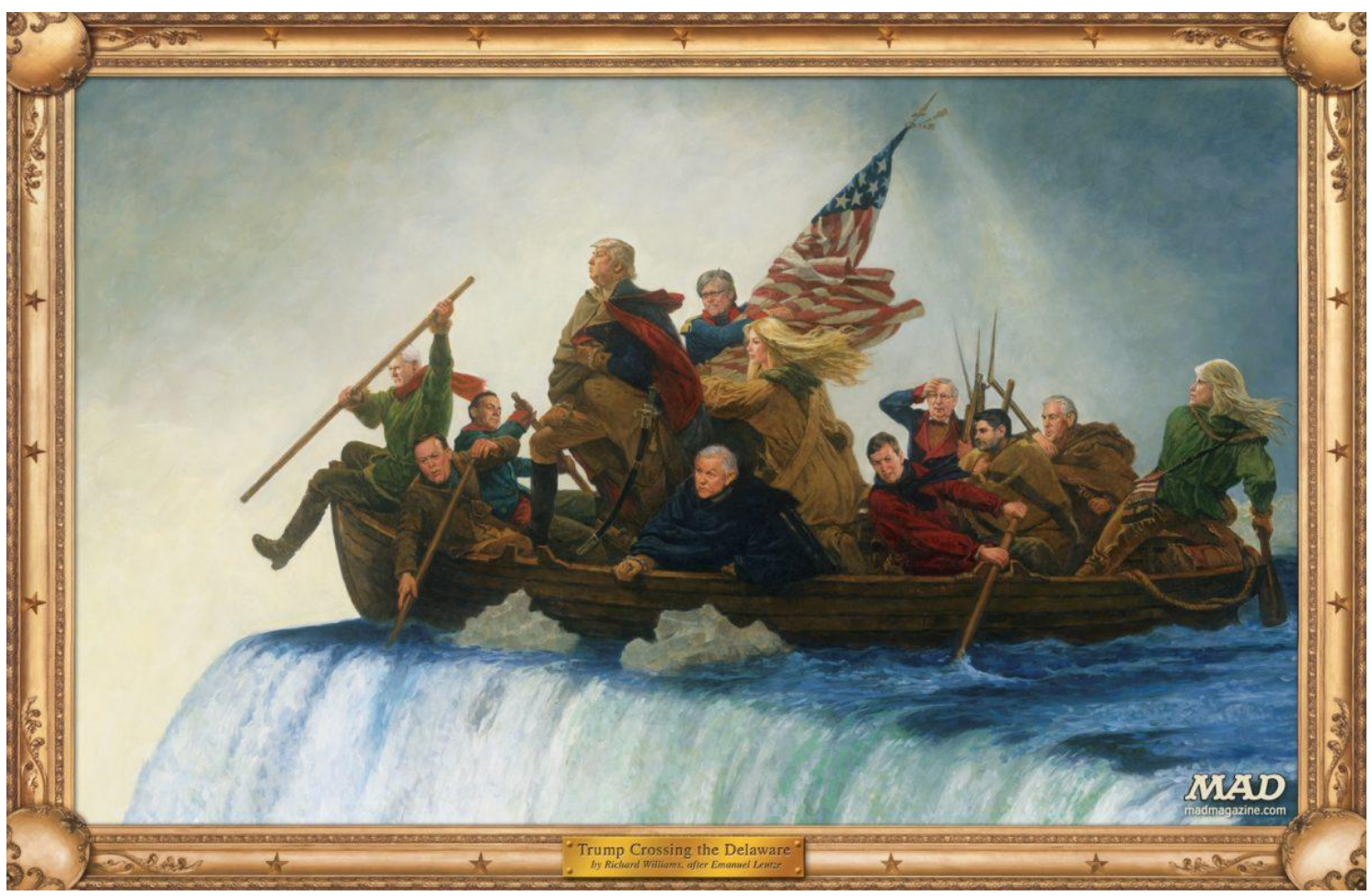

Image 7: Image published in the satire magazine MAD as a criticism to the government of president Donald Trump.

This leads to a strictly visual conversation around the use and representations of the past via the reproduction and manipulation of virtual images. A debate that, in this case, revolves around two poles: legitimisation and criticism. All of this based on a visuality easily recognisable by all its potential recipients, who are able to recognise immediately the underlying memory discourse of those images, capturing their attention and facilitating their reproduction. We must once again reiterate that what is being reproduced are the most obvious elements of the moment represented, unburdened from any depth, without context, lightened up. A representation and use of the past that must be related to the "aesthetic memory",

In this one, the source for the messages and images of the painting can be found in other previous works of art devoted to mass consumption ${ }^{61}$. In this type of memory, the historic videogame [the

\footnotetext{
${ }^{61}$ In this case, although we may be speaking of a painting of a historic event form the 19th century, it is necessary to define it as a mass medium, because, according to Tomás Pérez Viejo: "it is worth assuming that the constant presence of a specific historic event in the press and literature, its currency, was what must have urged the painter to choose it, becoming an echo chamber for a specific opinion, in Tomás Pérez Viejo. España imaginada: historia de la invención de una nación. (Barcelona: Galaxia Gutenberg, 2016), page 31. And, in this case, even if the painting was painted in Germany, its success was gigantic in the United States as it channelled a generalised opinion about Washington, transforming a minor episode of the war of independence into a mythical event, that raced to the top by itself, placing itself at the
} 
work of art for mass consumption] does not search for the veracity of what is represented or historic authenticity, searching in documents or testimonies from the past, it searches for it by being similar to previous master mediations of great influence, generating a media historicity that self-perpetuates in time through its reproduction ${ }^{62}$.

Understood as such, the painting by Leutze is seen as a "master mediation"63, as an unavoidable referent to represent the patriotism during the mythical moments of the foundation of the United States. A way of remembering that is light and instantaneous, that has been used in many occasion during those years, transforming the image's superficiality but maintaining the basic icons that manage to identify the resulting image with the original one, for example as in these images digitally created.

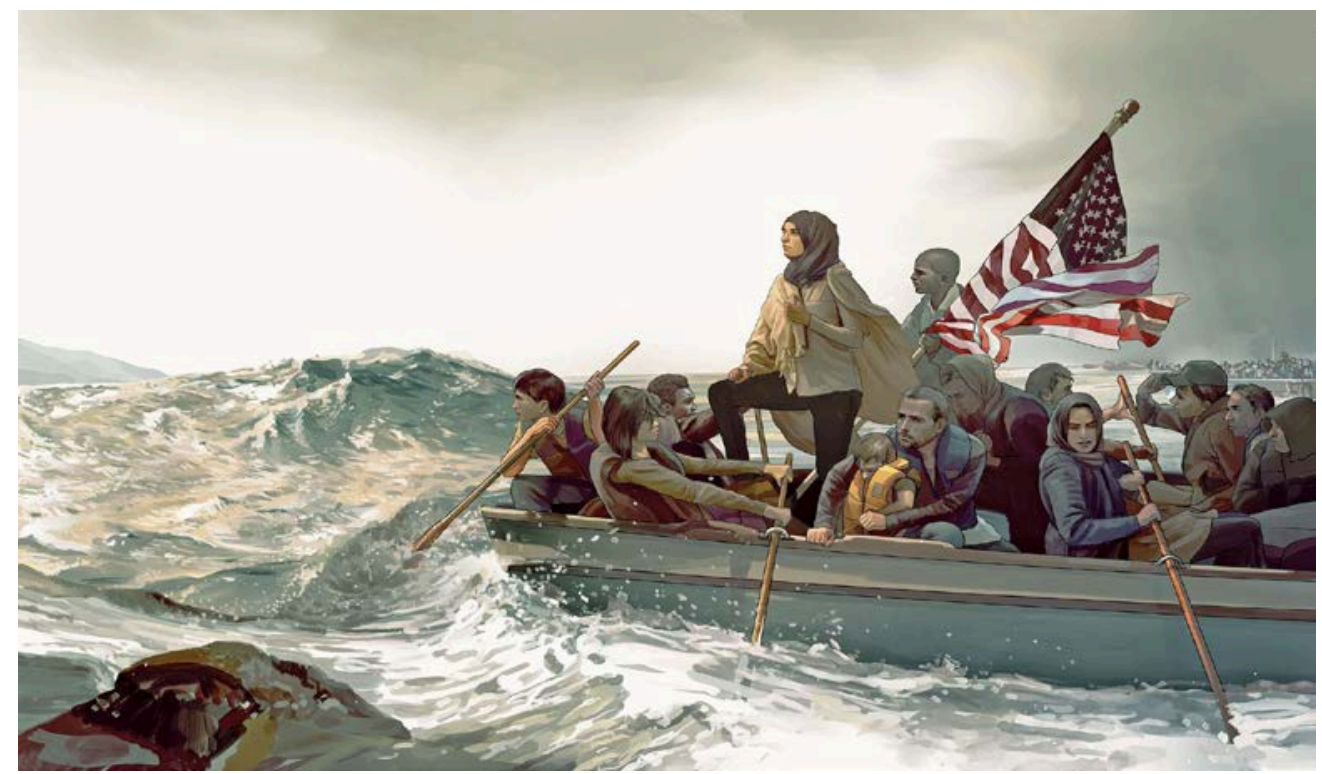

Image 8: This land is their land, digital work made by Owen Freeman to illustrate an article on the situation of refugees and migrants in $2017^{64}$.

service of the subsequent demands about the past David Lowenthal. El pasado es un país extraño (Barcelona: Akal, 2010), page 435.

${ }^{62}$ Alberto Venegas RAmos, Pasado interactivo..., op. cit., page 55.

${ }^{63}$ According to Debra Ramsay: "a representation of any medium that claims the status

of a definitive account of the war and of the wartime generation's experiences and memories and that subsequently functions as a touchstone for ensuing representations of the conflict throughout the transmedia structure."in Ramsay, Debra. American media and the memory of World War Two (New York: Akal, 2015), page 83. Even though Ramsay coined this concept specifically to define the role of the film Saving Private Ryan (Steven Spielberg, 1998) in the memory media ecosystem of the second world war, we now use this concept more broadly and understand it as touchstone references for all ensuing representations of this historic episode.

64 Suketu Mehta. "This Land Is Their Land". Foreing Policy. 12 ${ }^{\text {th }}$ of September, 2017, https://foreignpolicy.com/2017/09/12/this-land-is-their-land-america-europe-fear-of-migrants-trump/ 


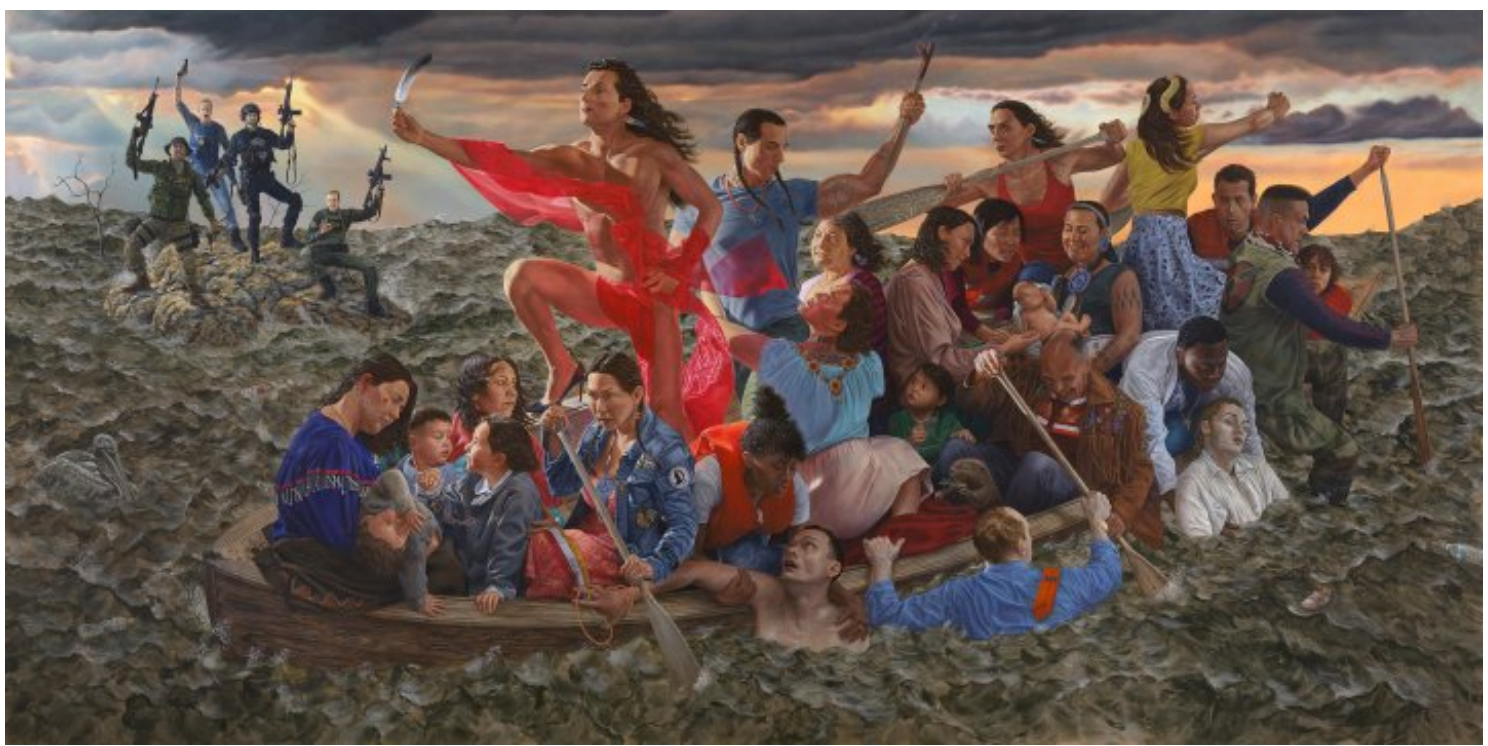

Image 9: Painting by Native American artist Kent Monkman painted in 2019: Welcoming the newcomers.

Those two images represent the same mythical moment of the past made popular by an image devoid of any context and transformed into a symbol, an unavoidable referent in the visuality of US patriotism. They all make a different use of the same past and create, amongst them, a debate that is resolved purely on a visual scenario. Some with the format of a meme, others as paintings, but all of them sharing the same space for reproduction and distribution, the virtual plane and the digital methods.

Nevertheless, some of them, as the painting by Monkman (image 9) and the image by Freeman (image 8) manage to be established as "counterimages", rejecting pure immediacy, changing the elements and above all, changing the deep meaning of the work of art by putting on the boat native Americans and on the island towards where they go or flee a group of armed men in the first image, and in the latter image, Syrian refugees. Both put at the forefront forgotten characters that question the present based on a well-known work of art of a mythologised past. According to Martínez Luna:

...the screen is ideological, as it establishes what is real with the construction of a dominant fiction for a specific society. The screen establishes who is visible according to specific imperatives of social differentiation and at the same time relegates to invisibility those who do not have space in the image repositories accumulated within $^{65}$.

\footnotetext{
${ }^{65}$ Sergio Martínez Luna. Cultura visual..., op. cit., page 91.
} 
Both images place at the forefront two groups of population considered as victims of the policies of the previous president of the United States ${ }^{66}$. They both reject the immediacy relationship and use visual composition to present a more dense content, more demanding for readers, forcing them to establish a more complex relationship with the original image and the new meaning. Even though this conclusion has been based around those two images, it can also be seen in the amount of memes published as a response to the appropriation by a group of Donald Trump's supporters of the painting (Image 5$)^{67}$, All of them constantly modify certain elements that are used to give a new meaning to the image. This new composition of the image with regard to the other referents present the characteristics of a dialectic image, once again as stated by Martínez Luna:

The encounter and the opposition of those images, the forms of solidarity and hostility between them, make them enter Benjamin's arena of dialectic images. It positions them as producers of knowledge, as elements to recreate the present and past. The dialectic image touches the past because it allows us to enter into unclosed pasts and ruled-out futures (...). The digital image is not the death of the image, nor is it the death of cinema, rather the reappearance of other histories and other lives for images. Their coming will, in any case, signal the end of a specific linear and teleological history of images, whose future feasibility has been paradoxically granted to digital images themselves. The fact that fixed images and moving images converge in the digital image opens up the possibility of seeing every image as changeable, perishable, ephemeral, and thus exploring the limits of unidirectional historic processes where they have been included and also silenced ${ }^{68}$.

\section{CONCLUSION}

To conclude, memes and all the images contained, created or reproduced with digital techniques in virtual spaces have become, due to their own importance in the media ecosystem, not only first-rate sources of information for historians, but also

\footnotetext{
66 Ezra Rosser. "Trump and the Native American vote". The Hill. 14 ${ }^{\text {th }}$ of October, 2020, https:/thehill.com/opinion/campaign/520899-trump-and-the-native-american-vote; and Amanda Holpuch. "Trump has nearly destroyed US refugee program, experts say". The Guardian. $28^{\text {th }}$ of September, 2019, https://www.theguardian.com/world/2019/sep/27/trump-refugee-cap-asylum-program

${ }^{67}$ Please refer to note 60 .

${ }^{68}$ Sergio Martínez Luna. Cultura visual..., op. cit., pages 136-137.
} 
places where discussions and struggles for the memory of certain episodes of the past are settled. Although we have selected a time period, the end of Donald Trump's presidency, and a specific topic, the memory relationship with the country's war of independence, this area of study with stages can be applied to many other spaces and images. We consider this to be a valuable contribution to the originality of the subject matter proposed, as well as to the method elaborated to approach it.

Moreover, this study is not only relevant because of the originality of the topic, but also because of its ability to approach from historic discipline a topic that, sooner or later, will have to be confronted: the imagery turnaround proposed by Mitchell and its relations with research and the social knowledge of the past. According to this art historian, as well as to many other theorists that came later, such as Malevich, the image has become a dominant medium in the circulation of information. That is why it is necessary to provide methodologies and an approach that manage to value and study in detail the relationship between images, the past and the job of historians, beyond merely using them as a source. In this paper, we have divided that methodology into two separate steps, first, the creation and distribution of an image and, secondly, the relationship established amongst the different images. Two stages that allow us to extract information from images and use them as sources and at the same time to analyse the dialectic relationship established around virtual images in general and memes in particular, with the purpose of understanding more deeply and structurally the uses of the past in the virtual world. Obviously this methodology is not definitive given the swiftness with which the subject matter changes, and thus the main problem is the difficulty to preserve and archive the original space where those images appear.

An image that, thanks to how easy it is to modify and distribute, is a platform for the use and representation of the past to achieve levels of social penetration never seen before, as we can imagine by the figures given in the footnotes regarding the dissemination of some memes. 


\section{BIBLIOGRAPHY}

Apter, Emily, "Alphabetic Memes: Caricature, Satire, and Political literacy in the Age of Trump", October Magazine, 170, 2019, pp. 5-24,

Aguado Cantabrana, Oskar y Pérez Mostazo, Juan. "Los bárbaros asaltan el Capitolio mientras Nerón incendia Washington", Proyecto ANIHO. Antigüedad, nacionalismos e identidades complejas en la historiografia occidental: Aproximaciones desde Europa y América Latina (1789-1989). 15 de enero de 2021, https://aniho.hypotheses.org/2075 [consulta 16 enero, 2021].

Bogerts, Lisa y Fielitz, Maik. "«Do You Want Meme War?»: Understanding the Visual Memes of the German Far Right.", en Post-digital cultures of the far right: Online actions and offline consequences in Europe and the US, coordinado por Fielitz, Maik y Thurston, Nick. (Verlag: Transcript, 2019). 137-153

Brea, José Luis. Las tres eras de la imagen (Barcelona: Akal, 2010).

Castells, Manuel. Redes de indignación y esperanza: los movimientos sociales en la era de internet (Madrid: Alianza, 2012).

Fontcuberta, Joan. La furia de las imágenes, (Barcelona: Galaxia Gutenberg, 2016).

Groseclose, S. Barbara. "Washington Crossing the Delaware:" The Political Context". American Art Journal, 7(2), 1975, pp. 70-78.

Lowenthal, David. El pasado es un país extraño (Barcelona: Akal, 2010).

Luelmo Jareño, José María. "La historia al trasluz: Walter Benjamin y el concepto de imagen dialéctica", Escritura e imagen, 3, 2007, pp. 163-176.

Makhortykh, Mykola. "Everything for the Lulz: Historical memes and World War II memory on Lurkomor'e". Digital Icons: Studies in Russian, Eurasian and Central European New Media, 13, 2015, pp. 63-90.

Márquez, Israel. Una genealogía de la pantalla. Del cine al teléfono móvil. (Barcelona: Anagrama, 2015).

Martín Prada, Juan. El ver y las imágenes en el tiempo de internet (Barcelona: Akal, 2018).

Martínez Luna, Sergio. Cultura visual, la pregunta por la imagen (Vitoria-Gasteiz: Sans Soleil, 2019).

Milner, M. Ryan. The World made meme. (Cambrige: The MIT Press, 2016).

Nagle, Angela, Muerte a los normies. Las guerras culturales en internet que han dado lugar al asceso de Trump y la "alt-righ", (Barcelona: Orciny Press, 2019).

Pavlyuk, Lyudmyla. "Memes as markers of fakes and propaganda topics in media representations of the russian-ukrainian conflict". Boletin de la Universidad 
Nacional “Politécnica de Lviv”. Serie: Ciencias Periodísticas, 3, 2019 pp. 8794.

Peirano, Marta. El enemigo conoce el sistema. (Barcelona: Barcelona, 2018).

Pérez Viejo, Tomás. España imaginada: historia de la invención de una nación. (Barcelona: Galaxia Gutenberg, 2016).

Ramsay, Debra. American media and the memory of World War Two (Nueva York: Routledge, 2015).

Ross, S. Andrew y Rivers, J. Damian. "Digital cultures of political participation: Internet memes and the discursive delegitimization of the 2016 US Presidential candidates". Discourse, Context \& Media, 16, 2017, pp. 1-11.

Schocket, M. Andrew. (2015). Fighting Over the Founders: How We Remember the American Revolution. (New York: NYU Press, 2015).

Shifman, Limor. Memes in digital culture. (Cambridge: The MIT Press, 2014).

Sinclair-Chapman, Valeria. "(De) Constructing symbols: Charlottesville, the confederate flag, and a case for disrupting symbolic meaning". Politics, Groups, and Identities, 6(2), 2018, pp. 316-323.

Todorov, Tzvetan. Los abusos de la memoria. (Barcelona: Paidós, 2013).

Veiga, Francisco, González-Villa, Carlos, Forti, Steven, Sasso, Alfredo, Prokoplijevic, Jelena, Moles, Ramón. Patriotas indignados: sobre la nueva ultraderecha en la Posguerra Fría: Neofascismo, posfascismo y nazbols. (Madrid: Alianza, 2019).

Venegas Ramos, Alberto. Pasado interactivo: memoria e historia en el videojuego (Vitoria-Gasteiz: Sans Soleil, 2020).

Wiggins, Bradley. The discursive power of memes in digital culture (Nueva York: Routledge, 2019). 